\title{
ADAT PERNIKAHAN SUKU BANJAR DAN SUKU BUGIS
}

\author{
M. Ahim Sulthan Nuruddaroini \\ Tarbiyah, Pascasarjana UIN Antasari Banjarmasin, Kalimantan Selatan, Indonesia \\ Muhahimsulthan@gmail.com
}

\begin{abstract}
Kebudayaan dan masyarakat adalah salah satu kesatuan yang tidak dapat dipisabkan satu sama lain, oleh karena itu dengan adanya masyarakat yang beraneka macam suku maka labirlah tradisi yang beraneka ragam pula. Selain itu kebudayaan dapat dipandang sebagai nilai-nilai yang diyakini bersama di dalam suatu masyarakat dan dapat terinternalisasi dalam diri individu sehingga terhayati dalam setiap perilaku, salah satunya ialah dalam adat perkawinan setiap suku memiliki perbedaan-perbedaan yang unik dan sangat menarik serta harus kita ketabui dan lestarikan, karena Indonesia sangat kaya akan budaya yang harus kita jaga bersama, dengan mengetabui perbedaan bukan berarti kita menghina dan menyalabkan justru saling menjaga dan saling menghargai satu sama lain. Tujuan Penelitian ini untuk mengetabui perbedaan dan persamaan adat perkawinan suku Banjar dan suku Bugis. Metode yang penulis gunakan adalah metode kualitatif. Jenis penelitian kepustakaan (library reseach), pendekatan yang digunakan adalah pendekatan etnografi dengan menelaah fenomena budaya yang ada di masyarakat. Hasil dari penelitian ini adalah adat perkawinan suku Banjar dan suku Bugis memiliki perbedaan dan persamaan. Perbedaan pertama tentang istilab uang yang diberikan kepada pihak perempuan dari pihak laki-laki dengan istilah uagjujuran (suku Banjar) dan uang panai (suku Bugis), sedangkan persamaannya yaitu sama-sama sesuatu hal yang harus dipenubi dalam adat perkawinan dan bentuknya juga sama berupa uang. Perbedaan selanjutnya tentang faktor-faktor yang mempengarubi tinggi rendahnya jumlah uang yang diberikan, kemudian dalam praktiknya juga memiliki perbedaan dan persamaan yang hampir mirip, hanya saja secara prosedural berbeda.
\end{abstract}

Kata Kunci: Adat, Pernikahan, Suku Banjar, Suku Bugis.

\begin{abstract}
Culture and society are one unity that cannot be separated from each other, therefore with the existence of various ethnic groups, various traditions are born. In addition, culture can be seen as values that are believed to be shared in a society and can be internalized in individuals so that they live in every behavior, one of which is in the marriage customs of each tribe that has unique and very interesting differences and we must know and preserve, because Indonesia is very rich in culture that we must guard together, by knowing the difference does not mean we insult and blame instead guard and respect each other. The purpose of this study was to determine the differences and similarities of the marriage customs of the Banjar and Bugis tribes. The method that I use is a qualitative method. Type of library research (library reseach), the approach used is an ethnographic approach by examining cultural phenomena that exist in society. The results of this study are the marriage customs of the Banjar and Bugis tribes that have differences and similarities. The first difference is about the term money given to women from the male side by the term nag jujuran (Banjar tribe) and panai money (Bugis tribe), while the equation is something that must be fulfilled in the custom of marriage and the same form money. The next difference is about the factors that influence the high and low amount of money given, then in practice it also has similar differences and similarities, only procedurally different.
\end{abstract}

Keywords: Tradition, Marriage, Banjar Tribe, Bugis Tribe.

\section{PENDAHULUAN}

Kebudayaan dan masyarakat adalah salah satu kesatuan yang tidak dapat dipisahkan satu sama lain, oleh karena itu dengan adanya masyarakat yang beraneka macam suku maka lahirlah tradisi yang beraneka ragam pula. selain itu kebudayaan dapat dipandang sebagai nilai-nilai yang diyakini bersama di dalam suatu masyarakat dan dapat terinternalisasi dalam diri individu sehingga 
M. Ahim Sulthan Nuruddaroini: Adat Pernikahan Suku Banjar...

terhayati dalam setiap perilaku, salah sarunya ialah dalam upacara perkawinan.(Koentjaraningrat, 2000)

Pelaksanaan perkawinan khususnya masyarakat Indonesia cenderung dilakukan dengan hukum adat, diantaranya adalah suku banjar dan suku bugis yang masih memegang erat adat istiadat dalam hal upacara perkawinan. Dalam pasal 2 undang-Undang No. 1 tahu 1974 tentang perkawinan, menjelaskan perkawinan haruslah mengikuti aturan yang ditetapkan oleh agama mempelai.

(bttp:// bukum.unsrat.ac.id/ma/ kompilasi, 2019) Akan tetapi dalam praktik perkawinan di Indonesia selain mengikuti peraturan agama, tradisi juga menjadi hal yang penting, seperti yang selalu dipraktikkan oleh masyarakat banjar dan bugis ketika mengadakan perkawinan yang penuh dengan berbagai adat istiadat baik sebelum, sesaat, ataupun sesudah perkawinan dilaksanakan.

Posesi perkawinan adat banjar dan adat bugis memiliki perbedaan-perbedaan istilah dan tahapan. Prosesi perkawinan adat banjar terdiri dari berbagai macam tahapan, diataranya ialah "Maantar Jujuran". Maantar ialah bahasa Banjar yang berarti mengantar, Jujuran adalah berupa harta yang bernilai seperti uang, perhiasan dan sebagainya yang diminta dari pihak perempuan terhadap pihak laki-laki. Dalam hal pembicaraan besar atau kecilnya jumlah jujuran seringkali terjadi tawar menawar, sehingga perundingan kadang harus dilakukan berkali-kali. Jujuran berbeda dengan mahar, mahar dalam Islam sepenuhnya menjadi hak bagi mempelai wanita, hal ini juga ditegaskan dalam pasal 32 bab V Kompilasi Hukum Islam tentang Mahar yaitu Mahar diberikan langsung kepada calon mempelai wanita dan sejak itu menjadi hak pribadinya.(bttp:/ / bukum.unsrat.ac.id/ ma/ kompilasi, 2019) Sedangkan jujuran bukan hak milik sepenuhnya untuk mempelai wanita seperti halnya mahar, selain itu jujuran tidak disebutkan ketika ijab Kabul seperti halnya mahar.

Berbeda dengan adat suku bugis, Perkawinan adat dalam suku Bugis Makassar disebut pa'bungtingan. Pa'bungtingan merupakan ritual yang sangat sakral dimana ritual tersebut harus dijalani oleh semua orang. Seorang gadis yang telah menginjak usia dewasa seharusnya sudah menikah. Jika tidak demikian maka akan mmenjadi bahan pembicaraan dikalangan masyarakat luas, sehingga terkadang orang tua mendesak si gadis untuk menikah dengan calon suami pilihan mereka.

Sebelum prosesi pa'bungtingan dilaksanakan, ada beberapa tahap yang harus dilalui oleh calon mempelai laki-laki. Salah satu diantaranya adalah assuro. Assuro adalah proses peminangan dari pihak keluarga calon mempelai laki-laki kepada pihak calon mempelai wanita, sekaligus penentuan pemberian uang panaik yang akan diberikan oleh calon mempelai laki-laki kepada pihak keluarga calon mempelai wanita apabila lamaran tersebut diterima.(Ikbal, 2016)

Masyarakat suku Bugis Makassar dan khususunya bagi masyarakat Kel. Untia Kec. Biringkanaya menganggap bahwa pemberian Uang panai dalam perkawinan adat mereka adalah suatu kewajiban yang tidak bisa diabaikan. Tidak ada Uang panai berarti tidak ada perkawinan. Kebiasaan inilah yang berlaku pada masyarakat suku Bugis Makassar di Kelurahan Untia Kecamatan Biringkanaya Kota Makassar sejak lama dan turun menurun dari satu periode ke periode selanjutnya sampai sekarang.(Ikbal, 2016)

Dari fenomena-fenomena di atas sangat menarik dikaji lebih dalam hal-hal tentang adatadat perkawinan dalam ke dua suku yaitu suku Banjar dan suku Bugis. Terlebih lagi tentang adatadat perkawinan yang memeliki persamaan maupun perbedaan dan tentunya memiliki budaya yang unik dan harus kita ketahui karena pada dasarnya di Negara Indonesia ini sangat kaya akan budaya-budaya maupun adat istiadat yang harus kita jaga dan kita lestarikan bersama.

\section{Masyarakat dan Tradisi}

Istilah masyarakat berasal dari bahasa Arab "syaraka" yang berarti ikut serta, berpartisipasi, atau "musyaraka" yang berarti saling bergaul. Adapun di dalam bahasa Inggris dipakai istilah "society" yang sebelumnya berasal dari kata lain "socius" berarti kawan. Menurut pendapat Abdul Syani kata masyarakat berasal dari kata musyarak yang artinya bersama-sama kemudian berubah menjadi masyarakat yang artinya berkumpul bersama, hidup bersama dengan saling berhubungan dan saling mempengaruhi, selanjutnya mendapatkan kesepakatan menjadi masyarakat.(Basrowi, 2005)

Untuk mendapatkan pemahaman yang utuh tentang masyarakat, maka disini akan dijelaskan 
beberapa definisi menurut para ahli sebagai berikut:(Basrowi, 2005)

Menurut Koentjaraningrat, masyarakat adalah kesatuan hidup manusia yang berinteraksi menurut suatu sistem adat istiadat tertentu yang bersifat kontinyu, dan yang terikat oleh suatu rasa identitas bersama. Sedangkan menurut Ralph Linton, masyarakat adalah sekelompok manusia yang telah cukup lama dan bekerja sama, sehingga mereka dapat mengorganisasikan dirinya sebagai salah satu kesatuan sosial dengan batas-batas tertentu.

Dari pendapat para ahli di atas, maka dapat disimpulkan bahwa masyarakat adalah suatu kelompok manusia yang hidup dalam waktu yang cukup lama dan bekerja sama satu dengan yang lainnya, serta memiliki kebiasaan, tradisi, pikiran dan perasaan yang menjadi bagian dari satu kesatuan kelompoknya.

Kata tradisi berasal dari bahasa latin yaitu traditio, artinya diteruskan atau kebiasaan. Hal yang paling mendasar dari tradisi adalah adanya informasi yang diteruskan dari generasi ke generasi baik tertulis maupun lisan, karena tanpa adanya ini, suatu tradisi dapat punah. (bttps://id.wikipedia.org/wiki/Tradisi., 2019)

Tradisi atau kebiasaan, dalam pengertian yang paling sederhana adalah sesuatu yang telah dilakukan sejak lama dan menjadi bagian dari kehidupan suatu kelompok masyarakat, biasanya dari suatu negara, kebudayaan, waktu, atau agama yang sama.(M. Kessing, 2006) Sedangkan menurut Kamus Besar Bahasa Indonesia, Tradisi adalah adat kebiasaan turun temurun dari nenek moyang yang masih dijalankan di masyarakat dengan anggapan tersebut bahwa cara-cara yang ada merupakan yang paling baik dan benar. (bttp:/ / kbbi.web.id/ tradisi., 2019)

Sebuah tradisi berdasarkan kepercayaan terhadap nenek moyang dan leluhur yang mendahului. Tradisi merupakan hasil cipta dan karya manusia objek material, kepercayaan, khayalan, kejadian, atau lembaga yang di wariskan dari sesuatu generasi ke generasi berikutnya, seperti adat-istiadat, kesenian dan properti yang digunakan. Tradisi yang telah membudaya akan menjadi sumber dalam berakhlak dan berbudi pekerti seseorang dan akan menciptakan kehidupan yang harmonis, jika manusia menghargai, menghormati dan menjalankan suatu tradisi secara baik dan benar serta sesuai aturan.
Melalui proses pewarisan, dari orang perorang atau dari generasi ke generasi lain, tradisi mengalami perubahan-perubahan baik dalam skala besar maupun kecil. Inilah yang dikatakan dengan invented tradition, dimana tradisi tidak hanya diwariskan secara pasif, tetapi juga direkonstruksi dengan maksud membentuk atau menanamkannya kembali kepada orang lain. Oleh karena itu, dalam memandang hubungan islam dengan tradisi atau kebudayaan selalu terdapat variasi interpretasi sesuai dengan konteks lokalitas masingmasing.(Khalil, 2008)

\section{Mahar, Hukum dan Batasan Mahar}

Setiap perjanjian yang terjadi antara dua orang atau lebih, akan mengakibatkan lahirnya hak dan kewajiban antara pihak-pihak yang melakukan perjanjian tersebut. Salah satu bentuk perjanjian ialah pernikahan antara laki-laki dan perempuan, maka secara otomatis lahirlah hak dan kewajiban satu sama lain. Salah satu diantara hak yang wajib diberikan oleh suami terhadap istrinya ialah memberikan mahar.(Wasl, 2013)

Mahar secara etimologi ialah sebuah pemberian, yang dalam bahasa arab nya shodak atau shidak, niblah. Mahar secara terminologis ialah, sesuatu yang diberikan dari pihak laki-laki kepada pihak perempuan sebagai imbalan atas bersenangsenang dengannya. Hal ini bukan berarti bahwa kehormatan seorang perempuan dinilai atau sebanding dengan nilai materi, tetapi mahar adalah bentuk penghormatan kepada perempuan.(Muhammad Amir, 2013)

Hukum memberi mahar sebagaimana yang telah disyari'atkan oleh Allah SW'T. Ialah wajib, baik itu dilakukan sebelum akad nikah atau ketika akad nikah, baik secara kontan ataupun dicicil, semua itu tergantung dengan kesepakatan antara dua belah pihak. Mahar yang telah diberikan oleh pihak laki-laki itu sepenuhnya hak bagi perempuan bukan untuk orangtua nya ataupun keluarganya. Mahar tidak boleh dipergunakan atau ditransaksikan oleh orang lain tanpa seizin dari perempuan tersebut.(Muhammad Amir, 2013, hlm. 52) Hal ini juga sesuai dengan yang tertulis dalam pasal 32-33 Kompilasi Hukum Islam(KHI) Bab V tentang Mahar.

Pasal Pasal 32 Mahar diberikan langsung kepada calon mempelai wanita dan sejak itu menjadi hak pribadinya. Pasal 33 (1) Penyerahan mahar dilakukan dengan tunai. (2) Apabila calon 
mempelai wanita menyetujui, penyerahan mahar boleh ditangguhkan baik untuk seluruhnya atau sebagian. Mahar yang belum ditunaikan penyerahannya menjadi hutang calon mempelai pria.(bttp:// hukum.unsrat.ac.id/ma/kompilasi,2019)

Namun demikian, di kalangan para ulama terdapat perbedaan pendapat mengenai kadar minimalnya mahar yang harus diberikan oleh suami kepada istrinya, menurut Syafiiyah tidak ada batasan minimal mahar artinya sah pemberian mahar dengan apa saja yang mempunyai nilai. Malikiyah menyebutkan batas minimal mahar ialah seperempat dinar emas atau tiga dirham perak dan yang senilai hal tersebut. Adapun Hanafiyah mengatakan batas minimal mahar adalah 10 dirham. Riwayat yang lain ada yang mengatakan 5 dirham, ada lagi yang mengatakan 40 dirham. (1 dinar $=4,25$ gram emas. dan 1 dirham $=2,975$ gram perak).(Ghazali, 2010)

\section{Hadiah Dalam Pernikahan}

Hadiah adalah pemberian sesuatu kepada seseorang dengan maksud untuk memuliakan atau memberikan penghargaan, dan juga hadiah bertujuan untuk mewujudkan kasih sayang diantara sesama manusia. Rasulullah Saw menganjurkan kepada umatnya agar saling memberikan hadiah. Karena yang demikian itu dapat menumbuhkan kecintaan dan saling menghormati antara sesama.

Sebelum menginjak ketahap pernikahan, biasanya diawali dengan peminangan atau kbitbah yaitu pihak keluarga laki-laki mendatangi rumah pihak perempuan untuk menanyakan serta meminta perihal ingin menikahkan anak lakilakinya kepada anak perempuan yang dimaksud. Tidak jarang ketika acara khitbah atau dalam jangka waktu menuju pernikahan, pihak laki-laki memberikan sejumlah hadiah berupa barangbarang yang diberikan kepada pihak perempuan.

Dalam hal ini para Ulama berbeda pendapat mengenai status hadiah tersebut, menurut Hanafiyah pemberian tersebut dikategorikan dalam hibah oleh karena itu pihak yang memberi tetap mempunyai hak untuk minta kembalikan barang tersebut. Syafi'iyah dan Malikiyah mengatakan jika laki-laki memberikan suatu hadiah kepada perempuan, kemudian terjadinya pembatalan peminangan atau batalnya ke tahap pernikahan, jika yang mebatalkan pihak laki-laki maka tidak ada hak bagi laki-laki atas pengembalian hadiah tersebut, namun jika yang membatalkan itu pihak perempuan maka wajib bagi perempuan mengembalikan hadiah tersebut baik langsung dengan 'ain benda nya atau bisa dihitung sesuai nilainya. Hanabilah pemberian tersebut sama dengan mahar artinya jika suami istri sudah dukhul maka hadiah itu sepenuhnya sudah menjadi hak istri artinya tidak ada hak pengembalian lagi.(Abd Sattar, t.t.)

\section{METODE}

Penulis akan menitikberatkan pada pengolahan data secara kualitatif. Adapun proses penyimpulan datanya bertumpu pada kajian dan studi literatur. Secara metodologis, langkahlangkah yang akan penulis tempuh adalah sebagai berikut:

\section{Jenis Penelitian dan Pendekatan yang digunakan}

Adapun jenis dan pendekatan yang digunakan dalam penelitian ini adalah sebagai berikut:

Jenis penelitian ini termasuk penelitian kepustakaan (library reseach), yaitu suatu bentuk metodologi pengumpulan data dan informasi dengan bantuan buku-buku maupun hasil penelitian yang ada diperpustakaan, dan materi pustaka yang lainnya dengan asumsi bahwa segala yang diperlukan dalam bahasan ini terdapat didalamnya.(Surachmad, 2007) Data yang diambil langsung dari buku-buku dan hasil penelitian yang relevan dengan penelitian ini. Hal ini dilakukan karena sumber-sumber data yang digunakan adalah berupa data literatur.

Pendekatan yang digunakan. Pendekatan yang digunakan dalam penelitian ini adalah pendekatan etnografi. Kajian etnografi memfokuskan telaah fenomena budaya dan mempunyai karakteristik ataupun ciri yang berbeda berdasarkan paradigma, pendekatan, dan model-model yang khas.(Nasution, 2016)

\section{Sumber Data}

Sumber data yang digunakan dalam penelitian ini adalah berbentuk paper. Paper adalah sumber data yang menyajikan tanda-tanda berupa huruf. Artinya, dokumen atau literatur yang berupa karya ilmiah, baik buku, makalah, artikel, dan lainlain.(Jauhari, 2008, hlm. 35) Dalam penyusunan penelitian ini, sumber data yang digunakan adalah dari berbagai sumber yang relevan dengan 
pembahasan penelitian ini. Adapun sumber data dalam penelitian ini terdiri dari dua macam:

Sumber data primer. Sumber-sumber yang sifatnya primer ialah: Hasil penelitian yaitu tesis, skripsi dan jurnal. Sumber data sekunder. Sumber data Sekunder adalah data yang diperoleh lewat pihak lain, tidak langsung diperoleh oleh peneliti dari subjek penelitiannya. Data sekunder ini disebut juga dengan Data Tangan Kedua.(Jauhari, 2008, hlm. 3) Adapun data sekunder dalam penelitian ini, yaitu beragam literatur yang berhubungan dengan objek penelitian diantaranya; ilmu sosil budaya.

\section{Teknik Pengumpulan Data}

Adapun untuk memperoleh data-data yang relevan dalam penelitian ini, yaitu studi pustaka: Studi pustaka yaitu mengidentifikasi secara sistematis dan melakukan analisis terhadap dokumen-dokumen yang memuat informasi yang berkaitan dengan objek dan masalah penelitian yang akan dilakukan. Terdiri dari dua langkah yaitu kepustakaan penelitian dan kepustakaan konseptual meliputi artikel, jurnal, tesis, skripsi atau buku-buku yang ditulis oleh para ahli memberikan pendapat, pengalaman, teori-teori atau ide-ide tentang apa yang baik dan buruk, halhal yang diinginkan dan tidak dalam bidang masalah.

\section{Teknik analisis data}

Adapun langkah-langkah yang penulis tempuh untuk menganalisis adalah: Menggambarkan secara sistematis terlebih dahulu mengenai pemberian uang jujuran dan uang panaik dalam perkawinan adat suku Banjar dan adat suku Bugis, selanjutnya dianalisis dan disimpulkan.

\section{HASIL DAN PEMBAHASAN}

\section{Analisis Adat Perkawinan Suku Banjar dan Suku Bugis}

Setiap suku memiliki adat-adat masing dalam melaksanakan perkawinan, dalam hal ini terdapat dua suku yang berbeda yaitu suku Banjar dan suku Bugis. Tentunya memiliki perbedaan-perbedaan yang memiliki keunikan dan kelebihan masingmasing. Disini penulis hanya mengangkat tentang uang yang diberikan kepada pihak perempuan (banjar=uang jujuran) dan (bugis=uang panai $/$ dui' menre'), dari istilah yang berbeda ini sangat menarik untuk dikaji lebih dalam dari segi istilah penyebutan, jumlah uang yang diberikan dan kriteria prempuan yang sesuai dengan pemberian uang tersebut.

\section{Tradisi Uang Jujuran (Banjar) dan Uang Panai (Bugis)}

Dalam tradisi adat banjar Jujuran adalah pemberian dari pihak laki-laki kepada pihak perempuan, jujuran dapat berbentuk uang atau benda. Uang atau benda ini digunakan sebagai pembiayaan pesta pernikahan, dari mulai rias pengantin, sewa tempat, dan hal-hal terkait pernikahan lainnya. Selain untuk acara pesta pernikahan, uang jujuran sebagian digunakan sebagai bekal kedua mempelai untuk menghadapi kehidupan rumah tangga. Bahkan banyak dari masyarakat yang menggunakan uang jujuran sebagai mahar untuk akad nikah, baik digunakan seluruhnya ataupun sebagian. Sehingga hal ini yang membuat anggapan sebagian masyarakat bahwa jujuran dan mahar adalah hal yang sama.(Akbari, 2018)

Masyarakat berpendapat bahwa jujuran sebagai salah satu tradisi yang dilakukan dalam rangkaian acara pernikahan. Hal ini akan menjadi aneh, apabila tidak dilaksanakan dalam rangkaian acara pernikahan dan akan berdampak mendapatkan gunjingan di kalangan masyarakat karena dianggap tidak menghormati adat budaya.

Sebelum menentukan jumlah jujuran yang menjadi nilai pandang pangeran adalah rumah calon mempelai wanita dan tutur katanya. Karena apabila rumah itu dalam keadaan rapi dan tutur katanya baik, maka akan mencerminkan bahwa rumah mereka akan terurus dengan rapi dan anakanaknya terdidik dengan baik pula. Lebih jauh lagi, untuk menentukan jumlah jujuran tersebut. Pangeran menginap di rumah keluarga calon mempelai wanita. Hal ini dilakukan untuk melihat keseharian kehidupan calon mempelai wanita. Karena zaman dahulu kamar itu tidak tertutup, maka si pangeran dapat melihat calon mempelai wanita. dari mulai si calon mempelai wanita bangun hingga tidur lagi, yang di cari oleh si pangeran adalah wanita yang ketika bangun tidur menggulung rambutnya, hal ini di karenakan wanita zaman dahulu memiliki rambut yang panjang-panjang.

Kemudian si calon mempelai wanita membereskan tempat tidurnya, apabila terdapat kain dan sarung, di lipat hingga rapi, lalu membuka 
jendela. Setelah itu calon mempelai wanita pergi ke dapur untuk menghidupkan api untuk menanggar tungku yang nantinya digunakan untuk merebus air. Karena zaman dahulu masih menggunakan kayu sebagai bahan bakar. Kemudian, si calon mempelai wanita akan pergi ke sungai untuk mencari kayu bakar serta mengambil wudhu untuk menunaikan sholat. Kemudian berdandan serta menyiapkan makanan yang nantinya akan di sajikan untuk pangeran. Selain menginap di kediaman calon mempelai wanita, si pangeran membawa beras beserta ampas padinya, yang nantinya akan diberikan kepada si calon mempelai wanita untuk di bersihkan. Apabila beras tersebut masih memiliki ampas padi setelah di bersihkan oleh si calon mempelai wanita. Dapat di simpulkan bahwa wanita tersebut tidak teliti dalam mengurus keuangan rumah tangga. Oleh karena itu pangeran mencari wanita yang paling bersih dalam membersihkan ampas padi. Hal ini di lakukan oleh pangeran dari kampung ke kampung, sampai menemukan calon mempelai wanita yang memenuhi kriteria tersebut. Setelah itu pangeran melamar dan menentukan jumlah jujuran.(Akbari, 2018)

Sedangakan menurut adat bugis berbeda dengan adat banjar, jika adat banjar menyebutnya dengan uang jujuran maka adat bugis menyebutnya dengan uang panai. Secara sederhana, uang panaik/doi balanja (Makassar) atau dui" menre" (Bugis) atau uang belanja, yakni sejumlah uang yang diberikan oleh pihak mempelai laki-laki kepada pihak keluarga mempelai perempuan. Uang panaik tersebut ditujukan untuk belanja kebutuhan pesta pernikahan. Uang panaik memiliki peran yang sangat penting dan merupakan salah satu rukun dalam perkawinan adat suku Bugis Makassar. Pemberian uang panaik adalah suatu kewajiban yang tidak bisa diabaikan. Tidak ada uang panaik berarti tidak ada perkawinan.(Ikbal, 2016)

Adapun akibat hukum jika pihak laki-laki tidak mampu menyanggupi jumlah uang panaik yang di targetkan, maka secara otomatis perkawinan akan batal dan pada umumnya implikasi yang muncul adalah pihak keluarga lakilaki dan perempuan akan mendapat cibiran atau hinaan di kalangan masyarakat setempat.

Satu hal yang harus dipahami bahwa uang panaik yg diserahkan oleh calon suami diberikan kepada orang tua calon istri, sehingga dapat dikatakan bahwa hak mutlak pemegang uang panaik tersebut adalah orang tua si calon istri. Orang tua mempunyai kekuasaan penuh terhadap uang tersebut dan begitupun penggunaanya. Penggunaan yang dimaksud adalah membelanjakan untuk keperluan pernikahan mulai dari penyewaan gedung atau tenda, menyewa grup musik atau masyarakat setempat menyebutnya electone, membeli kebutuhan konsumsi dan semua yang berkaitan dengan jalannya resepsi perkawinan.(Ikbal, 2016)

\section{Analisis}

Jika dilihat dari uraian di atas, terdapat perbedaan istilah antara suku Banjar dan suku Bugis. Menurut suku Banjar uang yang diberikan kepada pihak perempuan dengan istilah uang jujuran. Berbeda dengan suku bugis, uang yang diberikan kepada pihak perempuan dari pihak lakilaki menyebutnya dengan istilah uang panai. Meskipun berbeda istilahnya tapi ada persamaannya yaitu sama-sama dari pihak laki-laki harus memberikan uang tersebut untuk diberikan kepada pihak perempuan. Jika hal ini tidak dilaksanakan maka dapat gunjingan, tidak menaati adat dan tidak ada perkawinan. Artinya sesuatu hal yang wajib ada untuk keberlangsungan perkawinan.

\section{Faktor Yang Mempengaruhi Jumlah Uang Jujuran (Banjar) dan Uang Panai (Bugis)}

Dalam adat banjar Jujuran memang identik dengan uang, akan tetapi tidak ada batasan minimal ataupun maksimal dari jumlah jujuran, karena besarnya jumlah jujuran adalah atas kesepakatan bersama. Akan tetapi besar atau kecilnya jumlah jujuran dapat dipengaruhi oleh beberapa faktor.(Akbari, 2018)

Pertama, jumlah jujuran tergantung pasaran daerah tersebut, maksudnya setiap daerah memiliki pandangan yang berbeda terhadap jumlah jujuran. Ada daerah yang menganggap bahwa Rp. 50 juta itu wajar sebagai pemberian jujuran. Akan tetapi daerah lain menganggap uang tersebut sangatlah besar. Hal ini dipengaruhi oleh pendapatan warga setempat. Sebagai contoh Di daerah Kabupaten Tabalong rata-rata harga pasaran jujuran gadis Rp. 50 juta, janda Rp. 15 juta dan anak pejabat Rp. 100 juta. Hal ini bisa saja berubah sesuai dengan kesepakatan di dalam pembicaraan ketika lamaran.

Kedua, status sosial orangtua si gadis maksudnya adalah apabila orangtua si gadis itu 
pejabat atau pengusaha maka jujurannya akan lebih banyak jumlahnya dibandingkan dengan anak petani ataupun guru. Hal itu juga akan berbeda, apabila orangtua si gadis adalah tokoh agama, maka akan lebih banyak jumlah jujurannya dibandingkan warga biasa.

Ketiga, tingkat pendidikan si gadis. Jumlah jujuran juga dapat dipengaruhi oleh tingkat pendidikan yang di tempuh oleh si gadis dikarenakan, masyarakat percaya bahwa ibu adalah tempat pendidikan pertama kali untuk anakanaknya kelak nanti. Sehingga apabila seseorang gadis memiliki tingkat pendidikan yang tinggi, maka jumlah jujuran untuk gadis tersebut akan meningkat sesuai dengan tingkat pendidikannya. Karena semakin tinggi tingkat pendidikan si gadis maka ilmu pengetahuannya akan semakin banyak dan sangat baik untuk keturunan-keturunannya kelak.

Keempat, kecantikan si gadis. Meskipun kecantikan itu relatif, masyarakat Banjar tetap membedakan jumlah jujuran apabila seseorang gadis itu memiliki paras yang lebih cantik dibandingkan gadis-gadis lainnya. Hal ini merupakan penghargaan kepada si gadis karena dapat menjaga kecantikkannya, sehingga banyak laki-laki yang ingin menjadikan si gadis sebagai istrinya.

Kelima, karena memang dikehendaki orangtua si gadis sebagai biaya perkawinan dan bakal hidup bagi mempelai. Dalam wawancara bersama ibu Asnawati, beliau menceritakan pengalamannya terkait tawar menawar mengenai jumlah jujuran. Pada awalnya anak beliau didatangi oleh laki-laki yang ingin melamarnya. Laki-laki tersebut merupakan anak yatim piatu dan hanya bisa memberikan jumlah jujuran sebesar Rp. 10 juta. Akan tetapi ibu Asnawati tidak menyetujui jumlah jujuran tersebut, lalu meminta untuk meningkatkan jumlah jujuran hingga sebesar Rp. 50 juta.

Hal ini bukan dikarenakan ingin mempersulit pihak laki-laki, akan tetapi uang jujuran tersebut digunakan sebagai biaya pesta pernikahan. Dari mulai sewa gedung, biaya konsumsi, biaya rias pengantin dan lainnya yang ditaksir sebesar Rp. 75 juta. Oleh karena itu ibu Asnawati meminta untuk meningkatkan jumlah jujuran bukan dikarenakan ingin mempersulit pihak laki-laki untuk dapat menikah dengan anaknya. Akan tetapi hal itu dilakukan agar pesta pernikahan yang sekali dalam seumur hidup untuk anak gadisnya meriah dan dari masing-masing pihak mengeluarkan uang untuk biaya pernikahannya yang seimbang. Karena bagaimanapun juga pernikahan ini bukan acara sepihak, melainkan acara kedua belah pihak.(Akbari, 2018)

Sedangkan dalam suku bugis Uang panaik yang diberikan oleh calon suami jumlahnya lebih banyak daripada mahar. Adapun kisaran jumlah uang panaik dimulai dari 25 juta, 30, 50 dan bahkan ratusan juta rupiah. Hal ini dapat dilihat ketika proses negosiasi yang dilakukan oleh utusan pihak keluarga laki-laki dan pihak keluarga perempuan dalam menentukan kesanggupan pihak laki-laki untuk membayar sejumlah uang panaik yang telah dipatok oleh pihak keluarga perempuan.

Mahar dan uang panaik dalam perkawinan adat suku Bugis Makassar adalah suatu kesatuan yang tidak dapat dipisahkan. Karena dalam prakteknya kedua hal tersebut memiliki posisi yang sama dalam hal kewajiban yang harus dipenuhi. Walaupun dalam hal ini uang panaik lebih mendapatkan perhatian dan dianggap sebagai suatu hal yang sangat menentukan kelancaran jalannya proses perkawinan. Sehingga jumlah nominal uang panaik lebih besar daripada jumlah nominal mahar.

Jika kisaran uang panaik bisa mencapai ratusan juta rupiah karena dipengaruhi oleh beberapa faktor, justru sebaliknya bagi mahar yang tidak terlalu dipermasalahkan sehingga jumlah nominalnya diserahkan kepada kerelaan suami yang pada umumnya hanya berkisar Rp. $10.000-$ Rp. 5.000.000, juta saja. Akan tetapi pada zaman sekarang mahar dominan berbentuk barang yaitu tanah, rumah atau satu set perhiasan. Hal tersebut dapat dilihat ketika prosesi akad nikah yang hanya menyebutkan mahar dalam jumlah yang kecil.

Tinggi rendahnya uang panaik merupakan bahasan yang paling mendapatkan perhatian dalam perkawinan Bugis Makassar, sehingga sudah menjadi rahasia umum bahwa itu akan menjadi buah bibir bagi para tamu undangan. Adapun penyebab tingginya jumlah uang panaik tersebut disebabkan karena beberapa faktor diantaranya:(Ikbal, 2016)

Pertama, status ekonomi keluarga calon istri. Semakin kaya wanita yang akan dinikahi, maka semakin tinggi pula uang panaik yang harus diberikan oleh calon suami kepada pihak keluarga calon istri. Dan begitupun sebaliknya, jika calon istri tersebut hanya dari keluarga petani yang pada 
umumnya kelas ekonomi menengah kebawah maka jumlah uang panaik yang dipatok relatif kecil.

Kedua, Jenjang pendidikan calon istri. Besar kecilnya jumlah nominal uang panaik sangat dipengaruhi oleh jenjang pendidkan dan kedudukan calon mempelai perempuan. Semakin tinggi tingkat pendidikan seorang perempuan, maka semakin banyak pula uang panaik yang harus diberikan dan jika tidak memberikan uang panaike dalam jumlah yang banyak, maka akan mendapatkan hinaan atau akan menjadi buah bibir di masyarakat. Hal ini karena masyarakat Kelurahan Untia beranggapan bahwa keberhasilan mematok uang panaik dengan harga yang tinggi adalah suatu kehormatan tersendiri. Tingginya uang panaik akan berdampak pada kemeriahan, kemegahan dan banyaknya tamu undangan dalam perkawinan tersebut.

Ketiga, Kondisi fisik calon istri. Semakin sempurna kondisi fisik perempuan yang akan dilamar maka semakin tinggi pula jumlah nominal uang panaik yang dipatok. Kondisi fisik yang dimaksud seperti paras yang cantik, tinggi dan kulit putih. Jadi, walaupun perempuan tersebut tidak memiliki status sosial yang bagus atau tidak memiliki jenjang pendidikan yang tinggi maka kondisi fisiknya yang yang dapat menyebabkan uang panaiknya tinggi.

Begitupun sebaliknya, walaupun perempuan tersebut tidak memiliki kondisi fisik yang sempurna atau bahkan memiliki fisik yang jelek, akan tetapi dia memiliki status sosial yang bagus seperti keturunan bangsawan, jenjang pendidikan yang tinggi atau memiliki jabatan dalam suatu instansi, maka itu akan menjadi tolak ukur tingginya jumlah uang panaik yang akan dipatok pihak keluarga perempuan.

Keempat, Perbedaan antara Janda dan Perawan. Terdapat perbedaan dalam penentuan uang panaik antara perempuan yang janda dan perawan di Kelurahan Untia Kecamatan Biringkanaya. Biasanya perawan lebih banyak diberikan uang panaik dari pada janda, namun tidak menutup kemungkinan bisa juga janda yang lebih banyak diberikan jika status sosialnya memang tergolong bagus.

\section{Analisis}

Pada uraian di atas, dalam hal jumlah uang yang diberikan kepada pihak perempuan memiliki beberapa perbedaan dan persamaan. Di antara persamaannya, jumlah uang yang diberikan sesuai kesepakatan kedua belah pihak. Selain itu ada beberapa faktor yang menyebabkan tinggirendahnya uang yang diberikan kepada pihak perempuan. Status sosial ekonomi, jika keluarga calon istri tergolong keluarga pejabat, pengusaha maka akan naik pula jumlah uang yang diberikan, sebaliknya jika status sosil ekonominya menengah ke bawah maka rendah pula uang yang diberikan kepada pihak perempuan. Jenjang/tingkat pendidikan calon, tingkat pendidikan menjadi faktor yang sama antara suku banjar dan bugis, tapi berbeda dalam hal alasan atau tujuannya, jika suku banjar faktor pendidikan menjadikan tolak ukur tingginya uang yang diberikan kepada pihak perempuan karena pendidikan menjadi kualitas untuk anak-anaknya kelak, semakin tinggi pendidikan calon istri maka semakin mahal.

Berbeda dengan suku bugis, yang menjadikan faktor tingginya karena akan menjadikan bahan cibiran masyarakat apabila tidak sesuai dengan jenjang pendidikan calon istri. Kondisi fisik/kecantikan calon istri, menurut suku banjar dan suku bugis kondisi fisik/kecantikan calon istri menjadi tolak ukur tingginya uang yang diberikan kepada pihak perempuan. Yang menjadikan perbedaan, suku banjar memandang fisik atau kecantikan sebagai tolak ukur tingginya uang yang diberikan hal ini diberikan karena calon istri telah menjaga kecantikannya sehingga banyak para lelaki yang ingin menjadikannya istri. Berbeda dengan suku bugis, jika calon istri memiliki paras cantik, putih meskipun tingkat social ekonomi dan pendidikannya rendah bisa menjadikan tingginya uang yang diberikan kepada calon istri. Begitupun sebaliknya, walaupun perempuan tersebut tidak memiliki kondisi fisik yang sempurna atau bahkan memiliki fisik yang jelek, akan tetapi dia memiliki status sosial yang bagus seperti keturunan bangsawan, jenjang pendidikan yang tinggi atau memiliki jabatan dalam suatu instansi, maka itu akan menjadi tolak ukur tingginya jumlah uang panaik yang akan dipatok pihak keluarga perempuan.

Faktor selanjutnya sesuai kehendak orang tua calon istri, dalam adat banjar karena memang dikehendaki orangtua si gadis sebagai biaya perkawinan dan bakal hidup bagi mempelai. Bukan untuk mempersulit pihak laki-laki, akan tetapi sebagai biaya perkawinan dan bakal hidup bagi mempelai, sehingga keputusan ada ditangan orang 
tua, hal ini berbeda dengan faktor adat bugis, yaitu perbedaan janda dan perawan, Terdapat perbedaan dalam penentuan uang panai antara perempuan yang janda dan perawan. Biasanya perawan lebih banyak diberikan uang panai dari pada janda, namun tidak menutup kemungkinan bisa juga janda yang lebih banyak diberikan jika status sosialnya memang tergolong bagus.

\section{Praktik uang jujuran (Banjar) dan uang panai (Bugis)}

Sebelum membicarakan mengenai jumlah jujuran, masyarakat Banjar selalu mengawali dengan tradisi Badatang. Badatang adalah istilah untuk prosesi lamaran yang dilakukan calon mempelai pria kepada keluarga mempelai wanita. Jadi ada tata krama dalam Badatang, yaitu menanyakan kepada pihak perempuan apakah sudah ada yang datang sebelumnya atau tidak. Walaupun kita tau bahwa kedua calon mempelai ini berpacaran sebelumnya. Tetapi tidak menutup kemungkinan bahwa sudah ada laki-laki yang Badatang sebelumnya. Apabila sudah ada yang pernah Badatang dan menayakan jujuran, maka pihak laki-laki tidak boleh melanjutkan bertanya mengenai jumlah jujuran yang diminta oleh keluarga mempelai wanita. Apabila terjadi, maka ini akan menjadi tindakan penghinaan terhadap keluarga pihak laki-laki yang badatang dan bertanya sebelumnya.

Ketika tidak ada pihak laki-laki yang melamar, maka pada saat Badatangan akan dimulai pertanyaan-pertanyaan mengenai jumlah jujuran yang diminta oleh pihak wanita. Pertanyaan ini tidak secara langsung, seperti "Berapa jumlah jujurannya? " karena hal ini di anggap tidak sopan, biasanya untuk menanyakan jumlah jujuran di gunakan bahasa-bahasa sindiran seperti "Berapa mintanya?" "Berapa yang kira-kira kami dapat bantu" Atau hal-hal sindiran lainnya.

Kemudian pihak perempuan akan menentukan jumlah jujuran yang di minta. Apabila jumlah jujuran di masyarakat sekitar 40 juta, maka pihak perempuan akan meminta jumlah jujuran sekitar 40 juta. Apabila pihak laki-laki tidak sanggup, maka pihak laki-laki akan meminta jumlah jujuran untuk di kurangi. Disinilah terjadi proses tawar-menawar. Walaupun terjadi tawarmenawar, jumlah jujuran ini sesuai dengan kemampuan dan keadaan, melihat sesuai dengan kepribadian perempuan dan laki-lakinya. Sehingga nanti akan terjadi kesepakatan di antara kedua belah pihak.

Apabila pihak laki-laki meminta jumlah jujuran terlalu sedikit dari yang diminta dari pihak perempuan hal ini dapat dianggap sebagai penghinaan terhadap pihak perempuan dan berakibat bahwa jujuran tidak akan di lanjutkan kepada tahap berikutnya yaitu pernikahan. Hal ini dikarenakan sebelum terjadinya pertemuan antara kedua pihak keluarga, biasanya telah dibicarakan mengenai besaran jumlah jujuran oleh kedua calon mempelai. Sehingga keduabelah pihak di rasa telah mengetahui patokan besaran jumlah jujuran. Sehingga apabila terjadi musyawarah dan pihak laki-laki menawar terlalu jauh dari pembicaraan sebelumnya, maka akan dianggap sebagai sebuah penghinaan. Sebaliknya, apabila pihak laki-laki dan pihak perempuan sepakat mengenai jumlah jujuran maka akan dilanjutkan pada tahap penyerahan jujuran. Jujuran itu semacam mahar yang berlaku pada masyarakat adat, namun tidak sama dengan mahar.(Akbari, 2018)

Sedangkan adat bugis, Dalam adat perkawinan Bugis terdapat beberapa tahapan untuk melangsungkan perkawinan dan salah satunya adalah penyerahan uang panai. Adapun proses pemberian uang panaik tersebut adalah sebagai berikut:(Ikbal, 2016)

Pertama, pihak keluarga laki-laki mengirimkan utusan kepada pihak keluarga perempuan untuk membicarakan perihal jumlah nominal uang panai. Pada umumnya yang menjadi utusan adalah tomatoa (orang yang dituakan) dalam garis keluarga dekat seperti ayah, kakek, paman, dan kakak tertua. Kedua, Setelah utusan pihak keluarga laki-laki sampai di rumah tujuan. Selanjutnya pihak keluarga perempuan mengutus orang yang dituakan dalam garis keluarganya untuk menemui utusan dari pihak laki-laki. Setelah berkumpul maka pihak keluarga perempuan menyebutkan harga uang panaik yang dipatok. Jika pihak keluarga calon suami menyanggupi maka selesailah proses tersebut. Akan tetapi jika merasa terlalu mahal, maka terjadilah tawar menawar berapa nominal yang disepakati antara kedua belah pihak.

Ketiga, Setelah terjadi kesepakatan antara kedua belah pihak, maka tahap selanjutnya adalah membicarakan tanggal kedatangan pihak keluarga laki-laki untuk menyerahkan sejumlah uang panaik yang telah disepakati. Keempat, selanjutnya adalah 
pihak keluarga laki-laki datang ke rumah pihak keluarga perempuan pada waktu yang telah disepakati sebelumnya dan menyerahkan uang panaik tersebut. Kelima, setelah uang panai diserahkan, tahap selanjutnya adalah pembahasan mahar apa yang akan diberikan kepada calon istri nantinya. Adapun masalah mahar tidak serumit proses uang panai. Mahar pada umumnya disesuaikan pada kesanggupan calon suami yang akan langsung disebutkan saat itu juga. Dalam perkawinan suku Bugis pada era sekarang ini umunya mahar tidak berupa uang, akan tetapi berupa barang seperti tanah, rumah atau perhiasan.

\section{Analisis}

Dari uraian di atas, ada beberapa perbedaan antara adat banjar dan adat bugis dalam praktik jujuran maupun uang panai.

Dalam adat banjar tidak langsung menanyakan perihal jujuran baik nomimal maupun tawar menawar melainkan dengan cara bedatang terlebih dahulu, jadi pihak laki-laki bedatang atau bisa dikatakan melamar, menanyakan apakah sudah ada yang badatang, karena untuk menjaga adab dan tata krama dalam adat banjar, jika belum ada maka dilanjutkan dengan menanyakan jumlah jujuran tetapi dengan cara yang baik dengan tidak secara langsung menanyakan melaikan dengan bahasa yang santun "berapa yang dapat saya bantu" dan disinilah terjadinya tawar menawar apabila pihak perempuan mematok nominal jujuran tinggi.

Berbeda dengan adat bugis, dalam praktik uang panai ada beberapa tahapan atau prosesprosenya, dan ini sedikit berbeda dengan adat banjar. Hal yang pertama dalam adat bugis yaitu pihak laki-laki mengutus utusan untuk membicaran perihal uang panai lazimnya yang diutus adalah tomatoa (orang yang dituakan) dalam garis keluarga dekat seperti ayah, kakek, paman, dan kakak tertua. kemudian pihak perempuan juga mengutus orang yang dituakan untuk menemui pihak laki-laki yang dating atau menyambut kedatangan pihak laki-laki dan membicarakan tentang uang panai. Dan disinilah terjadinya tawar menawar, jika sudah sepakat maka dilanjutkan dengan menetukan tanggal kedantangn laki-laki untuk menyerahkan uang panai tersebut. Kemudian pihak laki-laki menyerahkan uang panai yang telah disepakati. Setelah uang panai diserahkan maka dilanjutkan pembahasan tentang mahar, pada umumnya mahar tidak terlalu rumit seperti uang panai, karena sesuai dengan kemampuan lakilaki dan disebutkan ketika akad nikah dan dalam perkawinan suku Bugis pada era sekarang ini umunya mahar tidak berupa uang, akan tetapi berupa barang seperti tanah, rumah atau perhiasan.

Jadi dalam praktik adat banjar dan adat bugis terdapat perbedaan baik istilah dan prosesprosesnya.

Tabel 1 Perbedaan dan Persamaan Adat Suku Banjar dan Suku Bugis

\begin{tabular}{lcc}
\hline \multicolumn{1}{c}{ Aspek } & \multicolumn{1}{c}{ Banjar } & Bugis \\
\hline Pemberian & UangJujuran & Uang Panai \\
Uang dari pihak & & \\
laki-laki & & \\
Kepada Pihak & & \\
Perempuan & & \\
\hline
\end{tabular}

\begin{tabular}{|c|c|c|}
\hline $\begin{array}{l}\text { Faktor yang } \\
\text { mempengaruhi } \\
\text { Jumlah Uang } \\
\text { yang diberikan }\end{array}$ & $\begin{array}{l}\text { Jumlah } \\
\text { jujuran } \\
\text { tergantung } \\
\text { pasaran } \\
\text { daerah } \\
\text { tersebut. } \\
\text { Status sosial } \\
\text { orangtua si } \\
\text { gadis . } \\
\text { Tingkat } \\
\text { pendidikan si } \\
\text { gadis. } \\
\text { Kecantikan } \\
\text { si gadis. } \\
\text { Karena } \\
\text { memang } \\
\text { dikehendaki } \\
\text { orangtua si } \\
\text { gadis sebagai } \\
\text { biaya } \\
\text { perkawinan } \\
\text { dan bakal } \\
\text { hidup bagi } \\
\text { mempelai. }\end{array}$ & $\begin{array}{l}\text { Status } \\
\text { ekonomi } \\
\text { keluarga } \\
\text { calon istri. } \\
\text { Jenjang } \\
\text { pendidikan } \\
\text { calon istri. } \\
\text { Kondisi fisik } \\
\text { calon istri. } \\
\text { Perbedaan } \\
\text { antara Janda } \\
\text { dan Perawan. }\end{array}$ \\
\hline $\begin{array}{l}\text { Praktik Uang } \\
\text { Jujuran dan } \\
\text { Uang Panai }\end{array}$ & $\begin{array}{l}\text { Badatang. } \\
\text { Menanyakan } \\
\text { berapa } \\
\text { jumlah } \\
\text { jujuran } \\
\text { dengan } \\
\text { bahasa } \\
\text { sindiran atau } \\
\text { bahasa yang }\end{array}$ & $\begin{array}{l}\text { Pihak laki-laki } \\
\text { maupun } \\
\text { perempuan } \\
\text { mengutus } \\
\text { orang yang } \\
\text { dituakan. } \\
\text { Tawar } \\
\text { menawar }\end{array}$ \\
\hline
\end{tabular}




\begin{tabular}{lll}
\hline Aspek & \multicolumn{1}{c}{ Banjar } & \multicolumn{1}{c}{ Bugis } \\
\hline sopan & jumlah uang \\
"Berapa & panai. \\
mintanya?”, & Menentukan \\
"Berapa yang & tanggal \\
kira-kira & kedatangan \\
kami dapat & laki-laki. \\
bantu”. & Pihak laki-laki \\
& Pihak & menyerahkan \\
& perempuan & uang panai. \\
menentukan & Pembahasan \\
& jumlah & uang mahar. \\
jujuran. & \\
Penyerahan & \\
Jujuran. & \\
\hline
\end{tabular}

\section{PENUTUP}

\section{Simpulan}

Kebudayaan dan masyarakat adalah salah satu kesatuan yang tidak dapat dipisahkan satu sama lain, oleh karena itu dengan adanya masyarakat yang beraneka macam suku maka lahirlah tradisi yang beraneka ragam pula.

Dari hasil analisis paparan di atas, terdapat adat perkawinan dua suku yang penulis analisis tentang uang yang diberikan kepada pihak perempuan sebagai suatu adat perkawinan. Tardapat beberapa perbedaan serta persamaan yang hampir sama, misalnya dalam suku Banjar uang yang diberikan kepada pihak perempuan dinamakan dengan istilah uang jujuran sedangkan dalam suku Bugis hal itu dinamakan uang panai, hal ini sama-sama sesuatu yang harus dipenuhi ketika melaksanakan perkawinan, artinya jika tidak ada prosesi seperti itu maka tidak ada perkawinan. Selain itu juga faktorfaktor yang menjadikan jumlah uang tersebut bisa naik atau tinggi juga terdapat perbedaan maupun persamaannya. Begitu juga dengan praktiknya.

\section{Saran}

Karya ilmiah ini semoga dapat memberikan masukan dan bacaan yang bermanfaat, dalam tulisan ini menerangkan tentang analisis perbedaan dan persamaan adat perkawinan suku Banjar dan suku Bugis, dengan mengetahui perbedaan kita tidak selayaknya saling mencaci karena setiap budaya dan adat memiliki kelebihan masingmasing.
Bagi masyarakat Indonesia tentunya hal ini sangat bermanfaat untuk dijadikan sebuah informasi bahwa Negara Indonesia sangat kaya akan budaya dan adat istiadat. Dan bagi para pelajar, mahasiswa dan semua yang berkecimpung dalam dunia pendidikan hal ini bisa menjadi tambahan referensi bagi peneliti selanjutnya.

Penulis hanya manusia biasa yang tak pernah luput dari kelasahan karena manusia adalah tempat salah dan lupa. Oleh karena itu, apabila tulisan ini ada kesalahan mohon diberikan masukan serta saran-saran agar penulis bisa memperbaik serta menyempurnakan guna menghasilkan yang lebih baik dan sempurna. Insya Allah

\section{DAFTAR PUSTAKA}

Abd Sattar, M. (t.t.). Al-Ahwal Al-Syakbsiyah fi Syariah Islamiyah. Kairo: Jami;ah al-azhar.

Akbari, R. (2018). Jujuran Dalam Adat Banjar (Kajian Etnografis Hukum Islam Dalam Perkawinan Adat Banjar). UIN Syarif Hidayatullah Jakarta, Jakarta.

Basrowi. (2005). Pengantar Sosiologi. Bogor: Ghalia Indonesia.

Ghazali, A. R. (2010). Fiqh Munakahat. Jakarta: Prenada Media Group.

bttp:/ / bukum.unsrat.ac.id/ ma/ kompilasi. (2019).

bttp:/ / kbbi.web.id/tradisi. (2019).

https://id.wikipedia.org/wiki/Tradisi. (2019).

Ikbal, M. (2016). "Uang Panaik" Dalam Perkawinan Adat Suku Bugis Makasar. 06, 25.

Jauhari, H. (2008). Pedoman Penulisan karya Ilmiah. Bandung: Pustaka Setia.

Khalil, A. (2008). Islam Jawa Sufisme Dalam Etika Dan Tradisi Jawa. Malang: UIN-Malang Press.

Koentjaraningrat. (2000). Pengantar Ilmu Antropologi. Jakarta: PT Rineka Cipta.

M. Kessing, R. (2006). Cultural Anthropology, ter. Samuel Gunawan. Jakarta: Erlangga.

Muhammad Amir, H. A. (2013). Dbiya' an-nisa libayan abkam al-mar'ab fi Surat An-Nisa. Kairo: Alghod.

Nasution, R. (2016). Ketertindasan Perempuan dalam Tradisi Kawin Anom: Subaltern Perempuan Pada 
M. Ahim Sulthan Nuruddaroini: Adat Pernikahan Suku Banjar...

Suku Banjar dalam Perspektif Poskolonial. Jakarta:

Yayasan Pustaka Obor Indonesia.

Surachmad, W. (2007). Pengantar Penelitian Ilmiah,

(Dasar-Dasar, Metode Teknik). Bandung:

Tarsito.

Wasl, N. F. (2013). Mubadarot fi figh al-usrob wa addiyat. Kairo: Lajnah Kulliyah Syariah wal qonun. 